\title{
The effect of problem-solving learning models on creative thinking skills in science subjects

\author{
Emelia Debora ${ }^{1}$, Heffi Alberida ${ }^{2,}{ }^{*}$, Ardi ${ }^{3}$, Siska Alicia Farma ${ }^{4}$ \\ Biology Education Department, Faculty of Mathematics and Science, Universitas Negeri Padang, \\ Indonesia \\ ${ }^{1}$ deboraemelia@gmail.com *, ${ }^{2}$ alberidamatua@gmail.com, ${ }^{3}$ ihfawa@gmail.com, ${ }^{4}$ Alishya.a@gmail.com \\ * Corresponding author
}

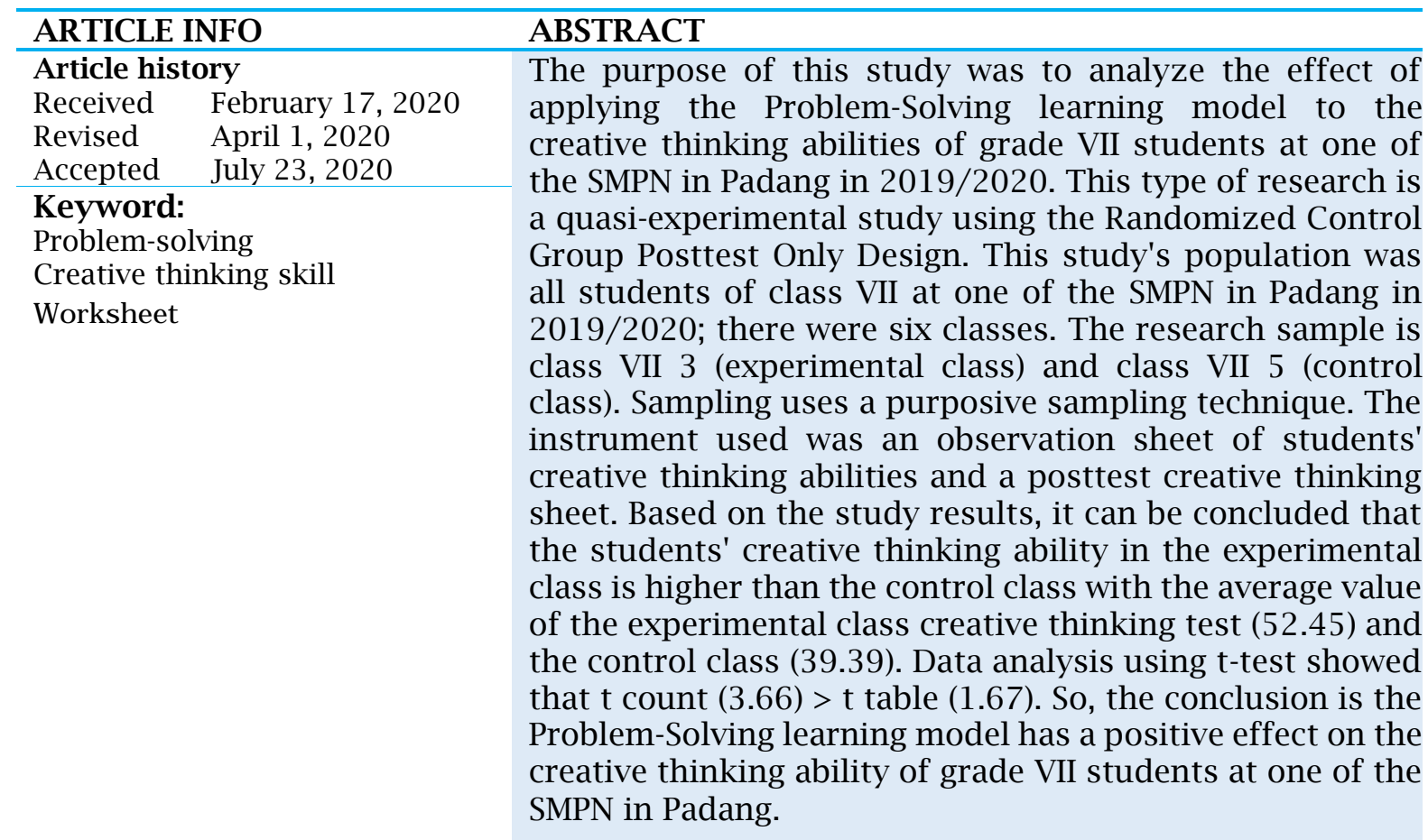

This is an open access article under the CC-BY-SA license.

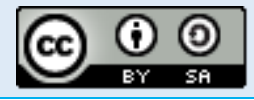

\section{Introduction}

The education system in the 21 st century is expected to improve the thinking skills of students. Following research conducted by Liliasari (2001), that to win a free competition in the globalization era of the 21st century, thinking skills need to be improved, especially higher-order thinking skills. High-level thinking can be grouped into 4 categories: problem-solving, decision making, creative thinking, and critical thinking. Based on the results of the Program International for Student Assessment (PISA) in 2018, the high-level thinking skills of Indonesian children are still low.

The education system can be seen from the current curriculum, namely the 2013 Curriculum. Learning in the 2013 curriculum prioritizes the activeness of students. Science learning at one of the SMPNs in Padang city, especially class VII, has not applied the student center principle. The subject matter is explained using the lecture, also question and answer method. Students' learning outcomes are also low due to a lack of motivation from the student. Based on the results of interviews with class VII science teachers, 
it is known that the teacher has difficulty focusing on students in learning, especially during afternoon lessons. This condition has an impact on the low learning motivation of students.

Lack of learning motivation, that affects learning outcomes may reflect thinking skills, such as students' creative thinking abilities. The observation questionnaire shows that the creative thinking ability of class VII students at one of the SMPN Padang city is low. The observation questionnaire of students' creative thinking abilities amounted to 5 multiple choice questions filled with 31 students. The total answer choices are 155, which are divided into 4 scores from lowest to highest. The results of the observation questionnaire on students' creative thinking skills are shown in Table 1.

Table 1. The results of an observation questionnaire on the creative thinking ability of class VII students at one of the Padang city junior high schools for the 2019/2020 academic year

\begin{tabular}{llcccc}
\hline \multirow{2}{*}{ No. } & \multirow{2}{*}{ Indicators of creative thinking } & \multicolumn{4}{c}{ Total (students) } \\
\cline { 3 - 5 } & & Skor $\mathbf{1}$ & Skor 2 & Skor 3 & Skor 4 \\
\hline 1 & Fluency & 11 & 15 & 2 & 3 \\
2 & Flexibility & 11 & 4 & 11 & 5 \\
3 & Originality & 15 & 8 & 4 & 4 \\
4 & Elaboration & 5 & 3 & 9 & 14 \\
5 & Metaphorical thinking & 12 & 5 & 2 & 12 \\
\multicolumn{2}{r}{ TOTAL } & 54 & 35 & 28 & 38 \\
\hline
\end{tabular}

Based on the Table 1, the total number of students who chose the lowest score (Score 1) was 54 people, score 2 was chosen by 35 people, score 3 was chosen by 28 people, and the highest score (Score 4) was chosen by 38 people. This comparison is a reflection of the low level of creative thinking skills of students because most students choose the lowest score. The results of the observation questionnaire show that the indicators of Fluency, Originality and Metaphorical thinking of students are classified as low, while the indicators of flexibility are classified as moderate. Furthermore, the Elaboration indicator is classified as high.

Efforts to improve students' creative thinking skills can be made by applying an appropriate learning model. Project-based learning and problem-based learning are ideal learning models to meet the goals of 21 st-century education because they involve the 4C principles: Critical thinking, Communication, Collaboration, and Creativity (Zubaidah, 2019). One of the problem-based learning models that is meet the 4C criteria is the Problem-Solving learning model.

Problem-Solving learning models have been widely researched and proven to improve learning outcomes, conceptual understanding, and problem-solving skills, increase motivation, learning outcomes and scientific performance activities (Festus \& Ekpete, 2012; Gök \& Sýlay, 2010; Karatas \& Baki, 2013). As well as the research results of Alberida, Lufri,
Festiyed, and Barlian (2018), stated that the Problem-Solving learning model using scientific steps could improve students' science process skills.

Based on the results of observations and interviews with teachers, several problems were identified in one of the SMPN city of Padang, namely the low motivation of students in learning science, the science lesson schedule was less conducive, the learning model used was less varied, the teacher more often used the lecture and question and answer method, the teacher less able to apply a studentcentered learning process, and the low ability of students to think creatively.

This study aims to determine the effect of the application of the ProblemSolving learning model on the creative thinking ability of grade VII students of one of the Padang City SMPNs for the $2019 / 2020$ academic year. The benefits of this research are as input for teachers to use the Problem-Solving learning model to improve students' creative thinking skills and as a basis for consideration for further researchers.

Creative thinking is related to originality, uniqueness, imagination, flexibility, fluency, making connections, forming new patterns, and personal expression, such as problem-solving, which is a basic skill of creativity (Greenstein, 2012). Experts have put forward several indicators of creative thinking. Treffinger, Young, Selby, and Shepardson (2002) suggest 5 indicators of creative thinking, 
namely: first, fluency, which is the ability to come up with many ideas, ways, suggestions, questions, ideas and alternative answers smoothly within a certain time. Fluency refers to the quantity or ability to generate a large number of ideas in response to open-ended questions or refers to a person's thought processes.

Next, flexibility is the ability to change the direction of someone's thinking or change someone's point of view. Flexibility involves being open to testing ideas in unexpected ways or in multiple ways. So, someone can come up with surprising and promising possibilities. A free, flexible and open environment is needed to stimulate creativity (Daud, Omar, Turiman, \& Osman, 2012). A flexible, practical, and willing mind to play with ideas and reverse them to achieve a brighter future good is the ability to think creatively (Kampylis \& Berki, 2014).

Furthermore, originality is the ability to generate new and unusual ideas. Originality is concerned with generating unusual choices (Treffinger et al., 2002). Creativity is more often defined in terms of a combination of novelty and originality, as well as value and utility. The dimensions of novelty and originality are strengthened by the emphasis on spontaneity and selfexpression in the act of creation (Glăveanu, 2018). The ability to think creatively is the individual's ability to use the mind to generate new ideas, new possibilities, and new discoveries based on originality in their production (Daud et al., 2012).

Next is elaboration, which is the ability to add details and expand on ideas. Elaboration involves making ideas more, more interesting, or more complete (Treffinger et al., 2002). A wider elaboration and accompanied by the search for distinctive features that are not divided by specific categories can contribute to obtaining new, more original concepts (Mumford, Medeiros, \& Partlow, 2012).

Lastly is metaphorical thinking, which is the ability to use comparisons or analogies to make new connections. Thinking metaphorically is thinking about something different that looks similar or different, then directing this connection to generate new possibilities (Treffinger et al., 2002). The ability to think creatively can be seen in terms of creating new ideas, creating analogies and metaphors. One of the important human abilities in creativity is combining objects and ideas in new ways (Daud et al., 2012).

The following are the reasons for teachers to encourage creativity in schools, according to Beetlestone (2012), namely: first, the education system needs to achieve a balance in the curriculum by developing all human capabilities (Human Resources), and emphasizing creative subjects with various ways of working which is also creative.

Furthermore, a period of anxiety over economic achievement and a great deal of concern for achieving a competitive position in the world market is very important to see how creative thinking can enrich economic potential. If education is about educating people to be ready to enter the world of work, then the ability to think creatively is needed. Finally, creativity is demanded by social reasons, which prove to be a force of positive energy. Creativity becomes a means to free the elements of a more productive personality.

Problem Solving can be defined as a series of learning activities that emphasize the process of solving problems faced scientifically. There are 3 main characteristics of Problem Solving, namely: 1) Problem Solving is a series of learning activities such as students actively thinking, communicating, looking for and processing data, and finally concluding; 2) Learning activities are directed to solve problems; 3) Problem-solving is done using a scientific thinking approach, using deductive and inductive thinking processes, and is carried out systematically and empirically (Komariah, 2011).

The stages of the Problem-Solving learning model for science learning according to Alberida et al. (2018), namely: introduction, observation, initial problem formulation, data/information collection, data organization, data analysis/ generalization, and communication.

\section{Method}

This type of research is a quasiexperimental research design with a randomized control group posttest only design. The research design used is shown in Table 2.

This research was conducted from August to October 2019. The population of this study was all grade VII students at one of the Padang City SMPNs for the 2019/2020 academic year, totaling 189 
people distributed into 6 classes. The research sample was students of class VII 3 and VII 5. The sample was taken by using the purposive sampling technique. Students in class VII 3 were selected as the experimental class, while class VII 5 was the control class.

Table 2. Randomized control group posttest only design

\begin{tabular}{lll}
\hline & Treatment & Posttest \\
\hline Experimental class & $\mathrm{X}$ & $\mathrm{T}$ \\
Control class & $\mathrm{O}$ & $\mathrm{T}$ \\
\hline Information: & \\
$\mathrm{X}=$ Treatment applies the problem-solving learning \\
model \\
$\mathrm{O}=$ Not given treatment \\
$\mathrm{T}=$ Posttest (Lufri \& Ardi, 2006)
\end{tabular}

This research procedure consists of three stages, namely the preparation, implementation, and completion stages. In the preparation stage, we were making a Learning Implementation Plan (RPP) and a student creative thinking observation questionnaire sheet, which is then validated, as well as preparing a validated creative thinking test sheet and Student Activity Sheet (LKPD). The next stage is the implementation stage, different learning steps are carried out in the two sample classes, namely in the experimental class using the Problem-Solving learning model while the control class uses the model commonly used by the teacher, namely the direct learning model. At the completion stage, the final test is given after learning one $\mathrm{KD}$ ends, then processing data on students' creative thinking skills, and finally drawing conclusions from the results obtained in accordance with the data analysis techniques used.

The research instrument used was the observation sheet of creative thinking abilities and posttest questions on students' creative thinking abilities. On the observation sheet of creative thinking abilities, there were 5 indicators of creative thinking abilities proposed by Treffinger et al. (2002), in sequence from numbers 1 to 5 are fluency, flexibility, originality, elaboration, and thinking metaphorically. Each indicator has four choices in sequence from the lowest score to the highest (options a, b, c, and d). Students choose one of the four choices by means of a cross (X).

The creative thinking problem used in this study was adapted from Fuad (2017) with some additions that do not change the contents of the questions so that this instrument is valid and reliable. This test consists of 8 questions containing the five indicators of creative thinking. I was given in the form of an essay that requires an answer in the form of explaining and elaborating. Posttest is given after the application of the Problem-Solving learning model in the Classification of Living Things material. This material is contained in KD 3.2, namely classifying living things and objects based on observed characteristics, so that the Competency Achievement Indicators used are describing and classifying living things.

There are indicators of creative thinking in the Classification of Living Things, for example, about the characteristics of living things. Students are expected to be able to explain what includes the characteristics of living things at a certain time. Here we can see the indicator of creative thinking, namely fluency (fluency in thinking). In explaining the characteristics of inanimate objects, students are expected to be able to explain these characteristics as much as possible according to their own thoughts so that the creative thinking indicator is originality (original thinking). When describing the differences between living things and non-living things, students are expected to be able to explain them in detail, detail and completely, so that indicators of creative thinking can be seen in elaboration (detailed thinking).

The hypothesis was tested by the two-mean t-test equality tests. Before the t-test is carried out, first, the normality test and the homogeneity test of the data are carried out as a requirement using the parametric test.

\section{Results and Discussion}

Based on the research, it was obtained data on the number of students who obtained scores on the creative thinking ability test. This test contains 5 indicators of creative thinking filled out by 31 students. The total score is 155 , which is divided into 5 (lowest score: score 0 to highest score: score 4 ). The number of students in the two sample classes for each score of creative thinking skills and the comparison of the results of the two-sample classes concluded that the highest score was 
obtained by the experimental class, while the lowest score was obtained by the control class. This condition means that the ability to think creatively in the experimental class is higher than the control class (See in Table 3).

Table 3. Number of students in each creative thinking indicator and score obtained

\begin{tabular}{|c|c|c|c|c|c|c|c|c|c|c|c|}
\hline \multirow{3}{*}{ No } & \multirow{3}{*}{$\begin{array}{l}\text { Creative Thinking } \\
\text { Indicator }\end{array}$} & \multicolumn{10}{|c|}{ Total (students) } \\
\hline & & \multicolumn{2}{|c|}{ Score 0} & \multicolumn{2}{|c|}{ Score 1} & \multicolumn{2}{|c|}{ Score 2} & \multicolumn{2}{|c|}{ Score 3} & \multicolumn{2}{|c|}{ Score 4} \\
\hline & & $\mathbf{E}$ & $\mathrm{C}$ & $\mathbf{E}$ & $\mathrm{C}$ & $\mathbf{E}$ & $\mathrm{C}$ & $\mathbf{E}$ & $\mathrm{C}$ & $\mathbf{E}$ & $\mathrm{C}$ \\
\hline 1 & Fluency & 1 & 1 & 4 & 15 & 9 & 9 & 10 & 2 & 7 & 4 \\
\hline 2 & Flexibility & 2 & 6 & 19 & 17 & 3 & 4 & 4 & 2 & 3 & 2 \\
\hline 3 & Originality & 0 & 0 & 12 & 14 & 9 & 12 & 7 & 4 & 3 & 1 \\
\hline 4 & Elaboration & 0 & 0 & 7 & 21 & 17 & 10 & 6 & 0 & 1 & 0 \\
\hline \multirow[t]{2}{*}{5} & Metaphorical thinking & 0 & 0 & 3 & 18 & 13 & 8 & 14 & 3 & 1 & 2 \\
\hline & TOTAL & 3 & 7 & 45 & 85 & 51 & 43 & 41 & 11 & 15 & 9 \\
\hline
\end{tabular}

Information:

$\mathrm{E}=$ Experimental class

$\mathrm{C}=$ Control class

The scores of students are converted into values of creative thinking skills. Based on the results of statistical calculations, the mean (X), standard deviation (S), and variance (S2) values of the two-sample classes are obtained in Table 4.

Table 4. Data description creative thinking ability

\begin{tabular}{lcccccc}
\hline \multicolumn{1}{c}{ Class } & $\mathbf{N}$ & Highest score & Lowest score & $\mathbf{X}$ & $\mathbf{S}$ & $\mathbf{S}^{\mathbf{2}}$ \\
\hline Experimental & 31 & 91 & 34 & 52.45 & 13.38 & 179.12 \\
Control & 31 & 84 & 22 & 39.39 & 14.68 & 215.58 \\
\hline
\end{tabular}

Based on Table 4, the average value of students' creative thinking abilities in the experimental class was higher than the control class. To find out the differences in creative thinking abilities in the sample class, then the two mean equation tests was carried out. To determine the test to be used, the normality test and the homogeneity test of the data are first carried out.
The Liliefors test is performed to determine whether the sample comes from a normally distributed population or not. The results of the normality test carried out will obtain L0 and L-table values at the 0.05 level. The results of the normality test that the researchers conducted are shown in the following Table 5.

Table 5. The results of normality test for creative thinking ability of sample class

\begin{tabular}{llllll}
\hline \multicolumn{1}{c}{ Class } & $\boldsymbol{\alpha}$ & $\mathbf{N}$ & $\mathbf{L}_{0}$ & \multicolumn{1}{c}{$\mathbf{L}$-table } & Distribution \\
\hline Experimental & \multirow{2}{*}{0.05} & 31 & 0.15 & 0.159 & Normal \\
Control & & 31 & 0.15 & 0.159 & Normal \\
\hline
\end{tabular}

Based on the Table 5, data on students' creative thinking abilities in the two sample classes are normally distributed. This is based on the value in the experimental class, namely ( $\mathrm{L} 0<\mathrm{L}$ table) and the value of the control class (L0 < L table). The homogeneity test used the F test. After calculating the two sample classes, the results of the homogeneity test of the creative thinking ability of the sample class are shown in the following Table 6 .

Based on the Table 6 , the results of the homogeneity test obtained F count $<$ F table. The value at the real level $\alpha=$ 0.05 with $\mathrm{dk}=30: 30$ is 1.84 . The results of data processing obtained the value of F-count $<$ F table, namely $1.20<1.84$, which means that the variance of these two classes is homogeneous.
Based on the normality test and homogeneity test that has been done, it shows that the two sample classes are normally distributed and the sample comes from a population that has a homogeneous variance, and then it can be continued by using the t-test. The results of the t-test for the creative thinking ability of the sample class are shown in the following Table 7 .

The Table 7 shows that the value of $t=$ 3.66 and t table $=1.67$. Hypothesis criteria are accepted if t-count $>t$-table. The results of the hypothesis test data analysis were $3.63>1.67$, which means that there were differences in the results of the creative thinking abilities of students in the experimental class and the control class, where the Problem-Solving learning model 
had a significant positive effect on students' creative thinking abilities.

The ability to think creatively is the ability that students have, including fluency, flexibility, originality, detailed thinking, and thinking metaphorically. The assessment of creative thinking abilities is obtained based on the rubric of assessing creative thinking abilities. There are 8 creative thinking questions that require answers to explain and describe. Posttest was given to the two-sample classes after being treated according to the application of their respective learning models.

Table 6. Homogeneity test results of creative thinking ability of sample class

\begin{tabular}{lrrrrrr}
\hline \multicolumn{1}{c}{ Class } & $\mathbf{N}$ & $\mathbf{S}^{2}$ & $\boldsymbol{\alpha}$ & $\mathbf{F}_{\text {count }}$ & $\mathbf{F}_{\text {table }}$ & Explanation \\
\hline Experimental & 31 & 179.12 & 0.05 & 1.20 & 1.84 & Homogen \\
Control & 31 & 215.58 & & & & \\
\hline
\end{tabular}

After processing the data on the scores obtained by students, there were differences in the scores between the experimental class and the control class. Based on data analysis, it can be seen that the creative thinking skills of class VII students at one of the SMPN Padang city are influenced by the learning model. Science learning with the Problem-Solving learning model can make students active and creative.
This finding is in accordance with the research of Tampubolon and Sitindaon (2013), that the Problem-Solving learning model can facilitate the success of students to solve problems related to learning materials, communication, group work, and can increase student learning activities. The results of Fadilah, Amin, and Lestari (2016) research reveal that the Problem-Solving learning model affects students' mathematical creative thinking abilities.

Table 7. Hypothesis test results of creative thinking ability of sample class

\begin{tabular}{cccccc}
\hline Class & $\boldsymbol{\alpha}$ & $\mathbf{N}$ & $\mathbf{S}^{\mathbf{2}}$ & $\mathbf{t}_{\text {- }}{ }_{\text {count }}$ & $\mathbf{t}_{\text {-table }}$ \\
\hline Experimental & \multirow{2}{*}{0.05} & 31 & 179.12 & \multirow{2}{*}{3.66} & \multirow{2}{*}{1.67} \\
Control & & 31 & 215.58 & & \\
\hline
\end{tabular}

In contrast to the control class, which applies the direct learning model, students tend to learn individually and are more passive in receiving information from the teacher. Students simply answer questions asked by the teacher or answer questions in the Science Literacy book. So that it affects the low ability of students to think creatively. The same thing was also reported in Fuad's research (2017) that the creative thinking skills of students in conventional classes tend to be low.

The steps of the Problem-Solving learning model are an introduction, observation, initial problem formulation, data/information collection, data organization, data analysis/generalization, and communication. This stage is in accordance with the LKPD that was distributed before starting the lesson. The implementation of the learning model for each meeting was observed by a VII grade science teacher at an SMPN city of Padang, and the implementation of the ProblemSolving learning model was generally well implemented.

The ability to think creatively on the Fluency indicator, the experimental class was in the highest score (Table 3). Fluency is the ability to come up with ideas or ideas smoothly within a certain time. This fluency indicator can be improved in the problem-solving learning process, especially at the initial problem formulation stage. At the initial problem formulation stage, students make a problem formulation based on the discourse in the LKPD. Students put forward their ideas, write problem formulations smoothly at the specified time. So that students can improve their Fluency creative thinking skills.

According to Siswono (2005), to develop students' creative activities in the learning process, a way is needed that encourages students to understand problems, improves creative thinking skills in planning solutions and involves students actively in finding their own problem solutions. The stage of formulating the problem is one of the scientific processes. Every meeting, the problem formulations written by students in the LKPD have increased. The impact of getting used to writing good and correct problem formulations can improve the scientific process of students. This is supported by the results of research by 
Alberida et al. (2018) that the ProblemSolving model improves the scientific process.

The ability to think creatively on the metaphorical thinking indicator in the experimental class is quite high (Table 3). Indicators of thinking metaphorically can be improved in the Problem-Solving learning process, especially in the data organization and data analysis/ generalization stages. At the data organization stage, students fill in the tables in the LKPD. Furthermore, in the data analysis/generalization stage, students answered the questions in the LKPD. In completing the empty table and answering the question, students combine several ideas, modify, and explain the formulation of ideas with logical and coherent analogies so as to improve indicators of thinking metaphorically. This shows that the ability to think creatively is improved in the initial problem formulation phase, data organization and data analysis/generalization in the Problem-Solving learning model.

The scores obtained by the experimental class in questions containing creative thinking indicators of Flexibility, Originality, and Elaboration were low. In Table 3, it can be seen that less than half of the students in the class obtained a total score of 3 and 4 . This shows that the ability to think creatively on the indicators of Flexibility, Originality, and Elaboration cannot be improved. The low score of the ability to think creatively on these three indicators is probably due to the low competency of students' knowledge due to a lack of motivation to learn.

The factors that influence learning consist of internal and external factors. Based on observations during the study, students experience internal factors such as fatigue, especially during afternoon lessons. The fatigue factor experienced by students is generally spiritual fatigue. Spiritual fatigue can be seen from the presence of lethargy and boredom so that interest and motivation to learn is reduced. Slameto (2010) states that spiritual fatigue can occur when constantly facing things that are always the same/constant without variation and doing things because they are forced and not in accordance with their talents, interests, and concerns.

External factors experienced by students include school factors. In its implementation, one of the SMPNs in
Padang lacks discipline, thus affecting the attitudes of students in learning and causing students to be less responsible. Students who do not carry out their duties are not given strict sanctions. Therefore, we need discipline in the learning process to develop strong learning motivation. This is in accordance with the opinion of Slameto (2010) so that students learn more advanced, students must be disciplined in learning at school, at home, and others. In order for students to be disciplined, teachers must be disciplined too.

Although in fact, there is no equalization between knowledge competence and the ability to think creatively. Slameto (2010) states that we should not make a separation between intelligence and creativity because intelligence plays only a small role in creative behavior. Furthermore, Slameto (2010) explains that the meaning of creative thinking is the same as divergent thinking, which is thinking in different directions so that unique but correct answers are obtained.

The teacher's role in giving example questions can also affect the creative thinking abilities of students. Teachers at one of the SMPNs in the city of Padang tend to give questions that are classified as easy, for example, daily test questions whose answers can be copied from books or science literacy Teachers do not provide examples of higher-order thinking questions to students. Teachers are advised to familiarize students with giving questions that spur higher-order thinking skills, especially creative thinking.

One of the reasons that creativity needs to be nurtured from an early age in students, according to Munandar (2012), is creative thinking as the ability to see various possible solutions to a problem. Munandar (2012) further states that creativity cannot be forced but must be cultivated by creating conditions of security and psychological freedom that allow constructive creativity to emerge.

Everyone can think and solve problems, but there are big differences in the skills of each individual. A problem cannot be solved without thinking and many problems require new solutions, and generating new ideas or ideas is the scope of problem-solving (Slameto, 2010). Furthermore, Slameto (2010) conveyed the steps needed in the formation of problemsolving skills that apply to the formation of 
creativity, so that the Problem-solving learning model that emphasizes problemsolving can improve students' creative thinking skills.

\section{Conclusion}

After text. Based on the results of the study, it can be concluded that the Problem-solving learning model has a positive effect on the creative thinking skills of grade VII students in one of the SMPN city of Padang. Based on the research carried out, there are several suggestions, namely 1) The Problem-solving learning model has systematic stages; it is advisable to the teacher to understand in detail these stages and allocate time properly so that the learning process can be in accordance with the objectives; 2) For other researchers, it is better to renew creative thinking questions and use other materials.

\section{References}

Alberida, H., Lufri, Festiyed, \& Barlian, E. (2018). Problem solving model for science learning. IOP Conference Series: Materials Science and Engineering, 335, 012084. https://doi.org/10.1088/1757899X/335/1/012084

Beetlestone, F. (2012). Creative learning: Strategi pembelajaran untuk melesatkan kreatifitas siswa (N. Yusron, Trans.). Bandung: Nusa Media.

Daud, A. M., Omar, J., Turiman, P., \& Osman, K. (2012). Creativity in science education. Procedia - Social and Behavioral Sciences, 59, 467474. $\quad$ https://doi.org/10.1016/ j.sbspro.2012.09.302

Fadilah, R. E., Amin, M., \& Lestari, U. (2016). Pengembangan buku ajar evolusi berbasis penelitian untuk mahasiswa S1 pendidikan biologi Universitas Jember. Jurnal Pendidikan, 1(6), 1104-1109. Retrieved from http://journal.um. ac.id/index.php/jptpp/article/view $/ 6425$

Festus, C., \& Ekpete, O. A. (2012). Improving students' performance and attitude towards chemistry through problem-based-solving techniques (PBST). International
Journal of Academic Research in Progressive Education and Development, 1(1), 167-174. Retrieved from https://www. researchgate.net

Fuad, N. M. (2017). Pengaruh model pembelajaran differentiated science inquiry dipadu mind map terhadap hasil belajar kognitif ipabiologi, ketrampilan berpikir kritis dan kreatid ditinjau dari gender pada siswa SMP Negeri Di Kabupaten Kediri (Universitas Negeri Malang). Retrieved from http://mulok.library.um.ac.id/inde x3.php/82001.html

Glăveanu, V. P. (2018). Educating which creativity? Thinking Skills and Creativity, 27, 25-32. https://doi. org/10.1016/j.tsc.2017.11.006

Gök, T., \& Sýlay, I. (2010). The effects of problem solving strategies on students' achievement, attitude and motivation. Latin-American Journal of Physics Education, 4(1), 7-21. Retrieved from http:// lajpe.org/jan10/02_Tolga_Gok.pdf

Greenstein, L. (2012). Assessing 21st century skills: A guide to evaluating mastery and authentic learning. Retrieved from https://books. google.co.uk

Kampylis, P., \& Berki, E. (2014). Nurturing creative thinking. Retrieved from https://www.ibe.unesco.org/sites/ default/files/resources/edu-practi ces_25_eng.pdf

Karatas, I., \& Baki, A. (2013). The effect of learning environments based on problem solving on students' achievements of problem solving. International Electronic Journal of Elementary Education, 5(3), 249268. Retrieved from http:// www.iejee.com/index.php/IEJEE/ar ticle/download/25/23

Komariah, K. (2011). Penerapan metode pembelajaran problem solving model polya untuk meningkatkan kemampuan memecahkan masalah bagi siswa kelas IX J di SMPN 3 Cimahi. Prosiding Seminar Nasional Penelitian, Pendidikan Dan Penerapan MIPA. Retrieved from https://eprints.uny.ac.id/7195/1/P M-25 - Kokom Komariah.pdf 
Liliasari, M. (2001). Model pembelajaran IPA untuk meningkatkan keterampilan berpikir tingkat tinggi calon guru sebagai kecenderungan baru pada era globalisasi. Jurnal Pengajaran Matematika Dan Ilmu Pengetahuan Alam, 2(1), 54-64. Retrieved from https://core.ac.uk/ download/pdf/194816394.pdf

Lufri, L., \& Ardi, A. (2006). Metodologi Penelitian: Penelitian Kuantitatif, PTK dan Penelitian Pengembangan. Padang: Universitas Negeri Padang.

Mumford, M. D., Medeiros, K. E., \& Partlow, P. J. (2012). Creative thinking: Processes, strategies, and knowledge. The Journal of Creative Behavior, 46(1), 30-47. https://doi.org/10.1002/jocb.003

Munandar, U. (2012). Pengembangan kreativitas pada anak berbakat. Jakarta: Rineka Cipta.

Siswono, T. Y. E. (2005). Upaya meningkatkan kemampuan berpikir kreatif siswa melalui pengajuan masalah. Jurnal Pendidikan Matematika Dan Sains,
10(1), 1-9. Retrieved from https://d1wqtxts1xzle7.cloudfront .net

Slameto. (2010). Belajar \& faktor-faktor yang mempengaruhinya. Jakarta: PT Rineka Cipta.

Tampubolon, T., \& Sitindaon, S. F. (2013). Pengaruh model pembelajaran problem solving terhadap hasil belajar siswa kelas X SMA Negeri 7 Medan. INPAFI (Inovasi Pembelajaran Fisika), 1(3), 260268. Retrieved from https://jurnal. unimed.ac.id/2012/index.php/inpa fi/article/view/1915

Treffinger, D. J., Young, G. C., Selby, E. C., \& Shepardson, C. (2002). Assessing creativity: A guide for educators. Retrieved from https://eric.ed.gov/ ?id=ED505548

Zubaidah, S. (2019). Pendidikan karakter terintegrasi keterampilan abad ke21. Jurnal Penelitian Dan Pengkajian Ilmu Pendidikan: ESaintika, 3(2), 1-24. https://doi. org/10.36312/e-saintika.v3i2.125 